\title{
Clinicopathological Data of Breast Cancer in Diabetic Patients
}

\author{
Azza M. Adel \\ Department of Clinical Oncology, Faculty of Medicine, Ain Shams University, Cairo, Egypt \\ Email: azzaelkhateeb@gmail.com
}

How to cite this paper: Adel, A.M. (2021) Clinicopathological Data of Breast Cancer in Diabetic Patients. Journal of Cancer Therapy, 12, 663-673.

https://doi.org/10.4236/jct.2021.1212058

Received: October 26, 2021

Accepted: December 7, 2021

Published: December 10, 2021

Copyright $\odot 2021$ by author(s) and Scientific Research Publishing Inc. This work is licensed under the Creative Commons Attribution International License (CC BY 4.0).

http://creativecommons.org/licenses/by/4.0/

\begin{abstract}
Background: Diabetes mellitus and breast cancer are both chronic diseases. Breast cancer in patients with diabetes is often diagnosed at an advanced stage and has worse prognosis. Aim of work: To investigate the clinicopathological factors, hormonal receptor status and molecular subtypes of breast cancer in diabetic breast cancer patients. Patients and methods: Records of patients presenting to the radiotherapy committee of the breast cancer clinic of Ain Shams University Hospital in the period between January 2017 and January 2018 were revised regarding age, presence of diabetes, presence of comorbidities, and type of the surgery performed. Pathological data such as: Tumor size (T), LN staging (LN), ER, PR, Her2/neu and Ki67 status were also recorded. Patients were divided into 2 groups: Group (I): those with diabetes and Group (II): those without diabetes. Inclusion criteria were Breast cancer cases with proven pathological diagnosis, available IHC studies, clear record of comorbidity status, age $>18$ years, cases who underwent upfront surgery. Exclusion criteria were metastatic cases, bilateral cases, cases with double primary, male breast cancer cases, and those with missing data for ER, PR and Her2/neu. Results: Retrieving data from the files of the patients that met the inclusion criteria in the allocated period revealed that 117 patients had diabetes (Group I) and 199 didn't have the disease (Group II), There was a highly significant difference between both groups regarding the age as most of the patients with diabetes were above fifty years of age (84.6\%) compared to only $44.7 \%$ of the patients without diabetes also the mean age of patients with diabetes was significantly higher (59 years) compared to 48 years of age for those without diabetes. Diabetes was associated with hypertension in most of the cases (69\%). Comorbidities other than hypertension were recorded in 39 diabetic patients (33.3\%) and $21(10.6 \%)$ nondiabetic patients and the difference was statistically highly significant. In the diabetic group, the most encountered comorbidity was cardiac disease in $14.5 \%$ of patients. In the diabetic group, most of the patients underwent modified radical mastectomy (MRM) with a percentage of about $54.7 \%$ compared to $48.2 \%$ of patients for both groups respec-
\end{abstract}


tively. Regarding pathological data apart from the finding that presence of diabetes was associated with more multiple tumors ( $p$ value: 0.013 ), no other statistically significant differences between both groups were found. Hormonal receptor status and molecular subtypes were also not affected by presence of diabetes in the studied breast cancer patients.

\section{Keywords}

Breast Cancer, Diabetes, Clinicopathological, Molecular Subtypes Running Head: Diabetes in Breast Cancer Patients

\section{Introduction}

Diabetes mellitus and breast cancer are both chronic diseases [1]. Comparable lifetime risk of $9.1 \%$ and $9.7 \%$ was encountered for diabetes and breast cancer respectively [2]. Diabetes is a major health problem in Egypt and The International Diabetes Federation (IDF) has considered Egypt among the world top 10 countries in incidence of diabetes with an estimated prevalence of $15.56 \%$ in those aging from 20 to 79 years [3]. Meanwhile in Egypt, breast cancer constitutes $33 \%$ of female cancer cases and more than 22,000 new cases are diagnosed each year [4].

Diabetes especially type 2 is linked to cancer risk [1] [5]. Breast cancer risk is increased by $15 \%$ to $23 \%$ in diabetic patients [6] [7]. Breast cancer in patients with diabetes is often diagnosed at an advanced stage compared to those without diabetes [8] [9]. Diabetes itself sharing some cancer-promoting factors such as obesity and sedentary lifestyle might have a direct effect on breast cancer prognosis [6]. Thirty to sixty percent higher mortality is reported in diabetic breast cancer patients [8].

Another reason for breast cancer survival being worse in diabetic patients may be that women with diabetes develop a different tumor subtype that could be more aggressive or less responsive to treatment [10] [11]. The mechanisms underlying the association between diabetes and risk of different breast cancer molecular subtypes are multiple but understudied [12]. Some mechanisms related diabetes and breast cancer risk to oncogenic effects of high insulin and insulin like growth factor (IGF) levels [13], which could relate to development of triple negative disease rather than estrogen receptor positive tumors [14].

Though association between diabetes and breast cancer is being extensively studied in the general population, few studies have assessed breast cancer subtypes in women with diabetes [15]. In the current study, it was aimed to investigate the clinicopathological factors, hormonal receptor status and molecular subtypes associated with breast cancer in diabetic patients.

\section{Patients and Methods}

This is a cross sectional observational study in which medical records of patients 
presenting to the radiotherapy committee of the breast cancer clinic of Ain Shams University Hospital in the period between January 2017 and January 2018 were revised regarding age, presence of diabetes (self reported), presence of hypertension, other comorbidities, and type of the surgery performed. Pathological data such as: Tumor size (T), LN staging (LN), presence of lymphvascular invasion (LVI), multiplicity of the tumor, presence of clinical inflammatory manifestations, presence of extracapsular extension, ER, PR, Her2/neu and Ki67 status were also recorded.

Hormonal receptors (ER and PR), HER2, and Ki67 were recorded and evaluated according to the guidelines of the breast clinic. HER2 was considered positive if $2+$ score SISH confirmed or 3+. Regarding Ki67 it was considered low if $\leq 14 \%$ and high if $>14 \%$ as per the St Gallen guidelines of 2013 [16], Molecular subtypes were defined as follows: HR+/HER2-, HR+/HER2+, HER2+ overexpressed (HER2 positive, HR-) and Triple Negative; TN (HER2 negative, ER negative and PR negative), HR was considered positive if any of ER or PR were found to be positive as per the guidelines of the breast clinic.

Patients were divided into 2 groups

Group (I): those with diabetes and Group (II): those without diabetes. Cases included in the study are the patients presenting after the primary treatment with surgery.

Inclusion criteria were: Breast cancer cases with proven pathological diagnosis, available IHC studies, clear record of presence or absence of diabetes, age > 18 years, cases who underwent upfront surgery. Exclusion criteria were metastatic cases, bilateral cases, cases with double primary, male breast cancer cases, and those with missing data for ER, PR and Her2/neu.

\section{Statistical Analysis}

Data were collected, revised, coded, and entered to the Statistical Package for Social Science (IBM SPSS) version 23. Quantitative data were presented as mean, standard deviations, median with inter-quartile range (IQR) and range while qualitative variables were presented as number and percentages. The comparison between groups with qualitative data was done by using Chi-square test. The confidence interval was set to $95 \%$ and the margin of error accepted was set to $5 \%$. So, the p-value was considered significant at the level of $<0.05$. $p<0.01$ : Highly significant.

\section{Results}

Retrieving data from the files of the patients that met the inclusion criteria in the allocated period revealed that 117 patients had diabetes (Group I) and 199 didn't have the disease (Group II).

There was a highly significant difference between both groups regarding the age as most of the patients with diabetes were above fifty years of age (84.6\%) compared to only $44.7 \%$ of the patients without diabetes also the mean age of 
patients with diabetes was significantly higher (59 years) compared to 48 years of age for those without diabetes (Table 1).

Diabetes was associated with hypertension in most of the cases (69\%). Comorbidities other than hypertension were recorded in 39 diabetic patients (33.3\%) and $21(10.6 \%)$ nondiabetic patients and the difference was statistically highly significant. In the diabetic group the most encountered comorbidity was cardiac disease in $14.5 \%$ of patients.

In the diabetic group most of the patients underwent modified radical mastectomy (MRM) with a percentage of about $54.7 \%$ compared to $48.2 \%$ of patients for both groups respectively. Breast conservative surgery (BCS) was less frequent among those with diabetes (36.8\% compared to $43.2 \%$ ) for both groups respectively.

Regarding pathological data apart from the finding that presence of diabetes was associated with more multiple tumors ( $p$ value: 0.013 ), no statistically significant difference between both groups regarding pathology of the tumor, grade of the tumor, $\mathrm{T}$ or $\mathrm{N}$ stage as shown in Table 2.

The pathological type of the tumor was not different between both groups as shown in Table 2. Lymphovascular invasion (LVI), was positive in about $20 \%$ of both groups. Inflammatory manifestations were present in $12 \%$ and $9 \%$ of both groups respectively. Extracapsular extension was recorded in $15.4 \%$ of diabetics and $24 \%$ of nondiabetics respectively.

Regarding the molecular subtypes and the hormonal status, there was none statistically significant difference in this regard between both groups (Table 3). Similarly, Ki67 level was not different between both groups, taking into consideration that it was reported for less than half of patients.

Regarding the effect of diabetes on the molecular subtypes, patients were classified by age into those less than 50 and those older than 50 , (Table 4 and Table 5). There was a none statistically significant difference between both groups when classified by age in hormonal receptor status, Her2/neu and molecular subtype.

\section{Discussion}

In the current study it was aimed to investigate whether diabetes affects the pathological data of breast cancer; in other words, it was meant to answer the question,

Table 1. Age of patients in both groups.

\begin{tabular}{cccccc}
\hline Age & $\begin{array}{c}\text { Group I } \\
\text { No. }=117\end{array}$ & $\begin{array}{c}\text { Group II } \\
\text { No. }=199\end{array}$ & Test value & p-value & Sig. \\
\hline Mean \pm SD & $58.88 \pm 9.65$ & $48.10 \pm 10.80$ & & & \\
Range & $35-85$ & $25-79$ & $8.911 \bullet$ & 0.000 & HS \\
Age $\leq 50$ & $18(15.4 \%)$ & $110(55.3 \%)$ & & & \\
Age $>50$ & $99(84.6 \%)$ & $89(44.7 \%)$ & $48.655^{*}$ & 0.000 & HS \\
\hline
\end{tabular}

p-value $>0.05$ : Nonsignificant; $\mathrm{p}$-value $<0.05$ : Significant; $\mathrm{p}$-value $<0.01$ : Highly significant; ${ }^{*}$ : Chi-square test; $\bullet$ : Independent t-test. 
Table 2. Clinicopathological data of both groups.

\begin{tabular}{|c|c|c|c|c|c|c|}
\hline & & $\begin{array}{c}\text { Group I } \\
\text { No. }=117\end{array}$ & $\begin{array}{l}\text { Group II } \\
\text { No. }=199\end{array}$ & $\begin{array}{c}\text { Test } \\
\text { value }\end{array}$ & p-value & Sig. \\
\hline \multirow[t]{3}{*}{ Hypertension } & Negative & $36(30.8 \%)$ & $170(85.4 \%)$ & & & \\
\hline & Positive & $81(69.2 \%)$ & $24(12.1 \%)$ & \multirow[t]{2}{*}{105.511} & \multirow[t]{2}{*}{0.000} & \multirow[t]{2}{*}{ HS } \\
\hline & NA & $0(\%)$ & $5(2.5 \%)$ & & & \\
\hline \multirow{3}{*}{$\begin{array}{l}\text { Comorbidities other } \\
\text { than hypertension }\end{array}$} & Present & $39(33.3 \%)$ & $21(10.6 \%)$ & \multirow{3}{*}{21.311} & \multirow{3}{*}{0.000} & \multirow{3}{*}{ HS } \\
\hline & Absent & $78(66.7 \%)$ & $162(81.4 \%)$ & & & \\
\hline & NA & $0(0 \%)$ & $16(8 \%)$ & & & \\
\hline \multirow{4}{*}{$\begin{array}{l}\text { Type of the surgery } \\
\text { performed }\end{array}$} & MRM & $64(54.7 \%)$ & $96(48.2 \%)$ & \multirow{4}{*}{5.254} & \multirow{4}{*}{0.072} & \multirow{4}{*}{ NS } \\
\hline & $\mathrm{BCS}$ & $43(36.8 \%)$ & $86(43.2 \%)$ & & & \\
\hline & SCM & $0(0 \%)$ & $4(2.1 \%)$ & & & \\
\hline & NA & $10(8.5)$ & $13(6.5 \%)$ & & & \\
\hline \multirow[t]{3}{*}{ Pathology } & IDC & $100(85.5 \%)$ & $172(86.5 \%)$ & \multirow{3}{*}{5.254} & \multirow{3}{*}{0.072} & \multirow{3}{*}{ NS } \\
\hline & ILC & $10(8.5 \%)$ & $17(8.5 \%)$ & & & \\
\hline & other & $7(6 \%)$ & $10(5 \%)$ & & & \\
\hline \multirow[t]{3}{*}{ Grade } & 1 & $0(0.0 \%)$ & $1(0.5 \%)$ & \multirow{3}{*}{2.117} & \multirow{3}{*}{0.347} & \multirow{3}{*}{ NS } \\
\hline & 2 & $98(83.8 \%)$ & $176(88.4 \%)$ & & & \\
\hline & 3 & $19(16.2 \%)$ & $22(11.1 \%)$ & & & \\
\hline \multirow[t]{4}{*}{ T stage } & $<2 \mathrm{~cm}$ & $20(17.1 \%)$ & $36(18.1 \%)$ & \multirow{4}{*}{7.172} & \multirow{4}{*}{0.127} & \multirow{4}{*}{ NS } \\
\hline & $2-5 \mathrm{~cm}$ & $63(53.9 \%)$ & $112(56.3 \%)$ & & & \\
\hline & $5 \mathrm{~cm}$ and more & $28(23.9 \%)$ & $44(22.1 \%)$ & & & \\
\hline & NA & $6(5.1 \%)$ & $7(3.5 \%)$ & & & \\
\hline \multirow[t]{4}{*}{$\mathrm{N}$ stage } & 0 & $24(20.5 \%)$ & $61(30.7 \%)$ & \multirow{4}{*}{4.138} & \multirow{4}{*}{0.247} & \\
\hline & From 1 - 3 LNs & $41(35.1 \%)$ & $66(33.2 \%)$ & & & NS \\
\hline & More than $3 \mathrm{LNs}$ & $44(37.6 \%)$ & $63(31.6 \%)$ & & & NS \\
\hline & NA & $8(6.8 \%)$ & $9(4.5 \%)$ & & & \\
\hline LVI & Negative & $35(29.9 \%)$ & $71(35.7 \%)$ & & & \\
\hline & Positive & $25(21.4 \%)$ & $40(20.1 \%)$ & 0.524 & 0.469 & NS \\
\hline & NA & $57(48.7 \%)$ & $88(44.2 \%)$ & & & \\
\hline Inflammatory & Negative & $101(86.3 \%)$ & $164(82.4 \%)$ & & & \\
\hline manifestations & positive & $14(12 \%)$ & $18(9.1 \%)$ & 0.382 & 0.536 & NS \\
\hline & NA & $2(1.7 \%)$ & $17(8.5 \%)$ & & & \\
\hline Extracapsular & Negative & $39(33.3 \%)$ & $63(31.7 \%)$ & & & \\
\hline extension & Positive & $18(15.4 \%)$ & $48(24.1 \%)$ & 2.148 & 0.143 & NS \\
\hline & NA & $60(51.3 \%)$ & $88(44.2 \%)$ & & & \\
\hline Multiplicity & Negative & $86(73.5 \%)$ & $167(84 \%)$ & & & \\
\hline & Positive & $24(20.5 \%)$ & $21(10.5 \%)$ & $6.137^{\star}$ & 0.013 & S \\
\hline & NA & $7(6 \%)$ & $11(5.5 \%)$ & & & \\
\hline
\end{tabular}

p-value $>0.05$ : Nonsignificant; p-value $<0.05$ : Significant; p-value $<0.01$ : Highly significant; *: Chi-square test; NA: Not Available, MRM: modified Radical mastectomy, BCS: Breast conservative surgery, SCM: Subcutaneous mastectomy, IDC: Invasive ductal carcinoma, ILC: invasive lobular carcinoma, T: Tumor stage, LNs: Lymph nodes, LVI: lymphovascular invasion. 
Table 3. Hormonal Receptor status and molecular subtypes of both groups.

\begin{tabular}{|c|c|c|c|c|c|c|}
\hline & & $\begin{array}{c}\text { Group I } \\
\text { No. }=117\end{array}$ & $\begin{array}{c}\text { Group II } \\
\text { No. }=199\end{array}$ & Test value & p-value & Sig. \\
\hline \multirow[t]{2}{*}{ ER } & Negative & $34(29.1 \%)$ & $53(26.6 \%)$ & \multirow{2}{*}{$0.229^{*}$} & \multirow{2}{*}{0.633} & \multirow{2}{*}{ NS } \\
\hline & Positive & $83(70.9 \%)$ & $146(73.4 \%)$ & & & \\
\hline \multirow[t]{2}{*}{ PR } & Negative & $37(33.0 \%)$ & $55(27.6 \%)$ & \multirow{2}{*}{$0.791^{\star}$} & \multirow{2}{*}{0.374} & \multirow{2}{*}{ NS } \\
\hline & Positive & $80(67.0 \%)$ & $144(72.4 \%)$ & & & \\
\hline \multirow[t]{2}{*}{ HER2/neu } & Negative & $88(75.5 \%)$ & $147(74.0 \%)$ & \multirow{2}{*}{$0.082^{*}$} & \multirow{2}{*}{0.774} & \multirow{2}{*}{ NS } \\
\hline & Positive & $29(24.5 \%)$ & $52(26.0 \%)$ & & & \\
\hline \multirow[t]{2}{*}{ Ki 67} & Negative & $13(11.1 \%)$ & $22(11.1 \%)$ & \multirow{2}{*}{0.083} & \multirow{2}{*}{0.773} & \multirow{2}{*}{ NS } \\
\hline & Positive & $32(27.4 \%)$ & $61(30.7 \%)$ & & & \\
\hline \multirow{4}{*}{$\begin{array}{l}\text { Molecular } \\
\text { subtype }\end{array}$} & $\mathrm{HR}+/$ Her2- & $68(58 \%)$ & $113(56.8 \%)$ & \multirow{4}{*}{$0.885^{\star}$} & \multirow{4}{*}{0.829} & \multirow{4}{*}{ NS } \\
\hline & $\mathrm{HR}+/ \mathrm{Her} 2+$ & $16(13.7 \%)$ & $35(17.6 \%)$ & & & \\
\hline & Her+ & $12(10.3 \%)$ & $19(9.6 \%)$ & & & \\
\hline & $\mathrm{TN}$ & $21(18 \%)$ & $32(16 \%)$ & & & \\
\hline
\end{tabular}

p-value $>0.05$ : Non significant; p-value $<0.05$ : Significant; p-value $<0.01$ : Highly significant; *: Chi-square test; ER; Estrogen Receptor, PR: Progesterone Receptor, Her2/neu: Human epidermal growth factor receptor 2. TN: Triple Negative, HR; Hormonal Receptor.

Table 4. Hormone receptor status and molecular subtypes in patients younger than 50 years.

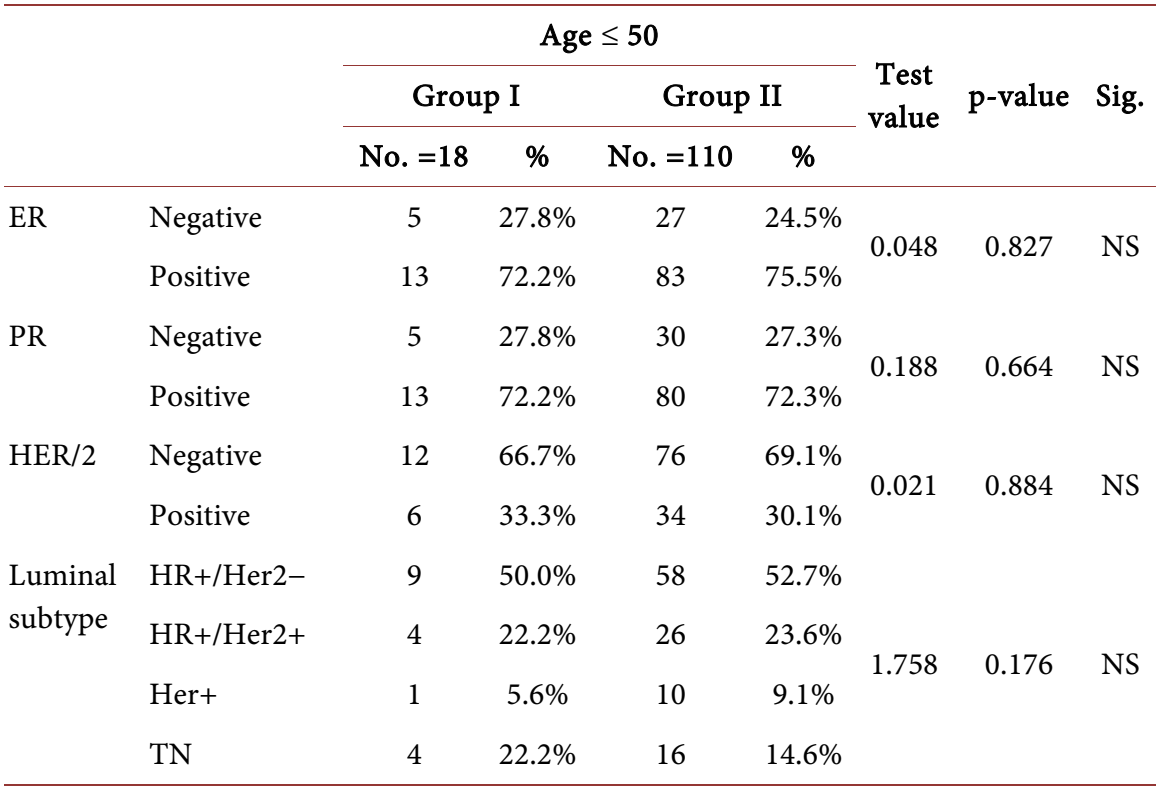

p-value $>0.05$ : Non significant (NS); p-value $<0.05$ : Significant (S); p-value $<0.01$ : highly significant (HS); ${ }^{*}$ :Chi-square test.

do those with diabetes develop a different disease than those without diabetes? Diabetes especially type 2 is a disease of the older age group so comparing epidemiologic data of both groups confirmed that diabetic patients were of older 
Table 5. Hormone receptor status and molecular subtypes in patients older than 50 years.

\begin{tabular}{|c|c|c|c|c|c|c|c|c|}
\hline & & & Age & $>50$ & & & & \\
\hline & & Grou & p I & Group & II & Test & p-value & Sig. \\
\hline & & No. $=99$ & $\%$ & No. $=89$ & $\%$ & & & \\
\hline ER & Negative & 29 & $29.3 \%$ & 26 & $29.2 \%$ & son & 0040 & NSC \\
\hline & Positive & 70 & $70.7 \%$ & 63 & $70.8 \%$ & 0.004 & 0.940 & No \\
\hline PR & Negative & 32 & $32.3 \%$ & 25 & $28.1 \%$ & 0400 & 0402 & NS \\
\hline & Positive & 67 & $67.7 \%$ & 64 & $71.9 \%$ & 0.492 & 0.400 & \\
\hline Her 2 & Negative & 76 & $76.8 \%$ & 71 & $79.8 \%$ & & & \\
\hline & Positive & 23 & $23.2 \%$ & 18 & $20.2 \%$ & & & \\
\hline Luminal subtype & HR+/Her2- & 59 & $59.6 \%$ & 55 & $62 \%$ & & & \\
\hline & $\mathrm{Hr}+/ \mathrm{Her}+$ & 12 & $12.1 \%$ & 9 & 10 & & & \\
\hline & Her+ & 11 & $11.1 \%$ & 9 & 10 & 0.441 & 0.932 & \\
\hline & $\mathrm{TN}$ & 17 & $17.2 \%$ & 16 & $18 \%$ & & & \\
\hline
\end{tabular}

p-value $>0.05$ : Non significant (NS); p-value $<0.05$ : Significant $(S) ;$-value $<0.01$ : highly significant (HS); ${ }^{*}$ :Chi-square test.

age, and it was found that the mean age of patients with diabetes was higher than nondiabetics. Diabetic breast cancer patients being older than nondiabetics were also reported in many studies [17] [18] [19].

Diabetes was associated with hypertension and cardiac diseases in the current study significantly. In this regard, Hou et al., reported on 1013 patients with breast cancer and diabetes compared to 4621 others without diabetes, that the diabetic group were elderly, postmenopausal with higher incidence of cardiovascular and cerebrovascular complications [17].

Regarding the pathologic data, apart from the tumor being multiple in more patients with diabetes, there was not a statistically significant difference between both groups in other pathological data.

Bronsveld et al. in a cross-sectional study using Danish Breast Cancer Cooperative Group data of 211 women with diabetes and 101 women without diabetes found that breast cancer patients with diabetes had a similar distribution of morphology, tumor size, and number of positive lymph nodes compared to those without diabetes [11]. This finding was different from other studies that reported on more advanced tumor stage and lymph node metastases in breast cancer diabetic patients [17] [20] [21].

Some biological mechanisms were linked to development of certain molecular subtypes of breast cancer, for example, the expression of IGF receptors has been found to be relatively higher in triple-negative breast cancer cells compared to estrogen responsive cells [14]. Elevated cytokine production [22] especially interleukin-6 and interleukin-8, was also liked to TN subtype [23].

In the current study, molecular subtypes of the disease were not affected by the presence of diabetes even after comparing both groups according to age. 
Previous studies regarding the association of diabetes with certain molecular subtypes were conflicting. While Palmer, et al. and Gross et al. reported a positive association with ER-negative disease and no association with ER-positive disease [18] [24], other studies reported the opposite such as Michels et al. and Maskarinec et al. who reported that there is a positive association with ER+ disease in patients with diabetes [19] [25]. Hou et al. reported that the diabetic patients had more negative PR expression [17].

Regarding the association of diabetes with triple negative TN disease, it was reported to be more associated with diabetes in many studies [12] [26] [27]. The association was statistically significant in the study carried by Chen et al., but it was nonsignificant in another two studies [11] [26]. Millikan et al. in a study of 225 TN patients reported on no association of triple negative disease with diabetes [28]. Lara-Medina et al. also reported the same [29]. Chen et al. also reported that Her2 Expression was more prevalent among diabetic patients though the association was statistically nonsignificant [12].

Future investigations are thus needed to further clarify the impact of diabetes on breast cancer hormonal status and molecular subtypes.

\section{Conclusion}

Both diabetes and breast cancer are chronic disease that are frequent among Egyptian females. Better understanding of the nature of breast cancer pathological data in diabetic patients is crucial for understanding prognosis of the disease. No predilection to certain molecular subtype of breast cancer among studied diabetic patients was found in the current study. Further research is needed in this topic.

\section{Limitations of the Study}

Due to the retrospective nature of the study; important data were missing from files such as the type and the treatment received for diabetes, duration of diabetes, the period between onset of diabetes and breast cancer diagnosis, compliance to systemic treatment, and BMI.

\section{Ethics Approval}

The necessary regulatory arrangements to use the data from records were done.

\section{Consent for Publication}

Not applicable.

\section{Conflicts of Interest}

The author declares no conflicts of interest regarding the publication of this paper.

\section{References}

[1] Zhao, X.-B. and Ren, G.-S. (2016) Diabetes Mellitus and Prognosis in Women with 
Breast Cancer. Medicine, 95, e5602.

[2] Forouzanfar, M.H., Foreman, K.J., Delossantos, A.M., Lozano, R., Lopez, A.D., Murray, C.J. and Naghavi, M. (2011) Breast and Cervical Cancer in 187 Countries between 1980 and 2010: A Systematic Analysis. The Lancet, 378, 1461-1484.

https://doi.org/10.1016/S0140-6736(11)61351-2

[3] International Diabetes Federation (2013) IDF Diabetes Atlas. 6th Edition, IDF, Brussels.

[4] Ibrahim, A.S., Khaled, H.M., Mikhail, N.N., Baraka, H. and Kamel, H. (2014) Cancer Incidence in Egypt: Results of the National Population-Based Cancer Registry Program. Journal of Cancer Epidemiology, 2014, Article ID: 437971. https://doi.org/10.1155/2014/437971

[5] Lam, E.K.K., Batty, G.D., Huxley, R.R., Martiniuk, A.L.C., Barzi, F., Lam, T.H., Lawes, C.M.M., Giles, G.G., Welborn, T., Ueshima, H., Tamakoshi, A., Woo, J., Kim, H.C., Fang, X., Czernichow, S. and Woodward, M. (2011) Asia Pacific Cohort Studies Collaboration. Associations of Diabetes Mellitus with Site-Specific Cancer Mortality in the Asia-Pacific Region. Annals of Oncology, 22, 730-738. https://doi.org/10.1093/annonc/mdq405

[6] Liao, S., Li, J., Wei, W., Wang, L., Zhang, Y., Li, J., Wang, C. and Sun, S. (2011) Association between Diabetes Mellitus and Breast Cancer Risk: A Meta-Analysis of the Literature. Asian Pacific Journal of Cancer Prevention, 12, 1061-1065.

[7] Starup-Linde, J., Karlstad, O., Eriksen, S.A., et al. (2013) CARING (CAncer Risk and INsulin analoGues): The Association of Diabetes Mellitus and Cancer Risk with Focus on Possible Determinants-A Systematic Review and a Meta-Analysis. Current Drug Safety, 8, 296-332. https://doi.org/10.2174/15748863113086660071

[8] Luo, J., Virnig, B., Hendryx, M., Wen, S., et al. (2014) Diabetes, Diabetes Treatment and Breast Cancer Prognosis. Breast Cancer Research and Treatment, 148, 153-162. https://doi.org/10.1007/s10549-014-3146-9

[9] Peairs, K.S., Barone, B.B., Snyder, C.F., Yeh, H.C., Stein, K.B., Derr, R.L., Brancati, F.L. and Wolff, A.C. (2011) Diabetes Mellitus and Breast Cancer Outcomes: A Systematic Review and Meta-Analysis. Journal of Clinical Oncology, 29, 40-46. https://doi.org/10.1200//CO.2009.27.3011

[10] Flores-López, L.A., Martínez-Hernández, M.G., Viedma-Rodríguez, R., Díaz-Flores, M. and Baiza-Gutman, L.A. (2016) High Glucose and Insulin Enhance uPA Expression, ROS Formation and Invasiveness in Breast Cancer-Derived Cells. Cellular Oncology, 39, 365-378. https://doi.org/10.1007/s13402-016-0282-8

[11] Bronsveld, H.K., Jensen, V., Vahl, P., De Bruin, M.L., Cornelissen, S., Sanders, J., Auvinen, A., Haukka, J., Andersen, M., Vestergaard, P. and Schmidt, M.K. (2017) Diabetes and Breast Cancer Subtypes. PLoS ONE, 12, e0170084.

https://doi.org/10.1371/journal.pone.0170084

[12] Chen, H., Cook, L.S., Tang, M.C., Hill, D.A., Wiggins, C.L. and Li, C.I. (2019) Relationship between Diabetes and Diabetes Medications and Risk of Different Molecular Subtypes of Breast Cancer. Cancer Epidemiology, Biomarkers \& Prevention, 28, 1802-1808. https://doi.org/10.1158/1055-9965.EPI-19-0291

[13] Gallagher, E.J. and LeRoith, D. (2010) The Proliferating Role of Insulin and Insulin-Like Growth Factors in Cancer. Trends in Endocrinology \& Metabolism, 21, 610-618. https://doi.org/10.1016/j.tem.2010.06.007

[14] Davison, Z., de Blacquière, G.E., Westley, B.R. and May, F.E. (2011) Insulin-Like Growth Factor-Dependent Proliferation and Survival of Triple-Negative Breast Cancer Cells: Implications for Therapy. Neoplasia, 13, 504-515. 
https://doi.org/10.1593/neo.101590

[15] Yang, X.R., Chang-Claude, J., Goode, E.L., et al. (2011) Associations of Breast Cancer Risk Factors with Tumor Subtypes: A Pooled Analysis from the Breast Cancer Association Consortium Studies. Journal of the National Cancer Institute, 103, 250-263. https://doi.org/10.1093/jnci/djq526

[16] Goldhirsch, A., Winer, E.P., Coates, A.S., Gelber, R.D., Piccart-Gebhart, M., Thürlimann, B. and Senn, H.J. (2013) Personalizing the Treatment of Women with Early Breast Cancer: Highlights of the St Gallen International Expert Consensus on the Primary Therapy of Early Breast Cancer 2013. Annals of Oncology, 24, 2206-2223.

[17] Hou, G., Zhang, S., Zhang, X., Wang, P., Hao, X. and Zhang, J. (2013) Clinical Pathological Characteristics and Prognostic Analysis of 1,013 Breast Cancer Patients with Diabetes. Breast Cancer Research and Treatment, 137, 807-816.

https://doi.org/10.1007/s10549-012-2404-y

[18] Palmer, J.R., Castro-Webb, N., Bertrand, K., Bethea, T.N. and Denis, G.V. (2017) Type II Diabetes and Incidence of Estrogen Receptor Negative Breast Cancer in African American Women. Cancer Research, 77, 6462-6469.

https://doi.org/10.1158/0008-5472.CAN-17-1903

[19] Michels, K.B., Solomon, C.G., Hu, F.B., Rosner, B.A., Hankinson, S.E., Colditz, G.A. and Manson, J.E. (2003) Type 2 Diabetes and Subsequent Incidence of Breast Cancer in the Nurses' Health Study. Diabetes Care, 26, 1752-1758. https://doi.org/10.2337/diacare.26.6.1752

[20] Wolf, I., Sadetzki, S., Gluck, I., Oberman, B., Ben-David, M., Papa, M.Z., Catane, R. and Kaufman, B. (2006) Association between Diabetes Mellitus and Adverse Characteristics of Breast Cancer at Presentation. European Journal of Cancer, 42, 1077-1082. https://doi.org/10.1016/j.ejca.2006.01.027

[21] Ali, A., Mohamed, M., Khattab, N., Tabl, A. and Emam, R. (2020) Relationship between Diabetes Mellitus and Clinicopathological Stages of Breast Cancer at Diagnosis. Benha Medical Journal, 37, 68-80.

[22] Rose, D.P., Komninou, D. and Stephenson, G.D. (2004) Obesity, Adipocytokines, and Insulin Resistance in Breast Cancer. Obesity Reviews, 5, 153-165.

https://doi.org/10.1111/j.1467-789X.2004.00142.x

[23] Hartman, Z.C., Poage, G.M., den Hollander, P., Tsimelzon, A., Hill, J., Panupinthu, N., Zhang, Y., Mazumdar, A., Hilsenbeck, S.G., Mills, G.B. and Brown, P.H. (2013) Growth of Triple-Negative Breast Cancer Cells Relies upon Coordinate Autocrine Expression of the Proinflammatory Cytokines IL-6 and IL-8. Cancer Research, 73, 3470-3480. https://doi.org/10.1158/0008-5472.CAN-12-4524-T

[24] Gross, A.L., Blot, W.J. and Visvanathan, K. (2019) Type II Diabetes and Subtype-Specific Breast Cancer Risk in Medically Underserved Black and White Women. Proceedings of the 2018 San Antonio Breast Cancer Symposium, San Antonio, 4-8 December 2018, San Antonio, 5-16-12.

[25] Maskarinec, G., Jacobs, S., Park, S.Y., Haiman, C.A., Setiawan, V.W., Wilkens, L.R. and Le Marchand, L. (2017) Type II Diabetes, Obesity, and Breast Cancer Risk: The Multiethnic Cohort. Cancer Epidemiology, Biomarkers \& Prevention, 26, 854-861. https://doi.org/10.1158/1055-9965.EPI-16-0789

[26] Crispo, A., Augustin, L.S., Grimaldi, M., Nocerino, F., Giudice, A., Cavalcanti, E., Di Bonito, M., Botti, G., De Laurentiis, M., Rinaldo, M., Esposito, E., Riccardi, G., Amore, A., Libra, M., Ciliberto, G., Jenkins, D.J. and Montella, M. (2017) Risk Differences between Prediabetes and Diabetes According to Breast Cancer Molecular 
Subtypes. Journal of Cellular Physiology, 232, 1144-1150.

https://doi.org/10.1002/jcp.25579

[27] Garcia-Esquinas, E., Guino, E., Castano-Vinyals, G., Perez-Gomez, B., Llorca, J., Altzibar, J.M., et al. (2016) Association of Diabetes and Diabetes Treatment with Incidence of Breast Cancer. Acta Diabetologica, 53, 99-107.

https://doi.org/10.1007/s00592-015-0756-6

[28] Millikan, R.C., Newman, B., Tse, C.K., Moorman, P.G., Conway, K., Dressler, L.G., et al. (2008) Epidemiology of Basal-Like Breast Cancer. Breast Cancer Research and Treatment, 109, 123-139. https://doi.org/10.1007/s10549-007-9632-6

[29] Lara-Medina, F., Perez-Sanchez, V., Saavedra-Perez, D., Blake-Cerda, M., Arce, C., Motola-Kuba, D., et al. (2011) Triple-Negative Breast Cancer in Hispanic Patients: High Prevalence, Poor Prognosis, and Association with Menopausal Status, Body Mass Index, and Parity. Cancer, 117, 3658-3669. https://doi.org/10.1002/cncr.25961 